\section{References}

1 E. Schmidt, W. Schurig and W. Sellschopp, Tech. Mech. Thermodyn. 1930, 1, 53-63

2 J. F. Welch, Ph.D. Thesis, University of Illinois, Urbana, 196

3 J. L. McCormick and J. W. Westwater, Chem. Eng. Sci, 1965 20, $1021-1036$

4 J. F. Welch and J. W. Westwater, Proc, of Second Int. Heat Transfer Conf., 1961, 2, 302-309

5 A. C. Peterson and J. W. Westwater, Chem. Eng. Prog. Symp. Ser., 1966, 62, (64), 135-142

6 A. Umur and P. Griffith, 7. Heal Transfer, 1965, 87, 275-282

7 S. Sugawara and K. Katsuta, Proc. of Third Int. Heat Transfer Conf., 1966, 2, 354-361

8 T. Takeyama and S. Shimizu, Proc. Fifth Int. Heat Transfer Conf., 1974, 3, 274-278

9 J. W. Westwater, in 'Heat Transfer in Energy Problems', edited by W. J. Yang, Hemisphere Publishing Co., Washington, D.C., in press

10 D. W. Tanner, D. Pope, C. J. Potter and D. West, Int. Y. Heat Mass Transfer, 1965, 8, 427-436

11 L. A. Bromley, J. W. Porter and S. M. Read, Am. Inst. Chem. Eng. Y., 1968, 14, 245-250

12 R. A. Erb, Gold Bull, 1973, 6, (1), 2-6

13 R. A. Erb and E. Thelen, Ind. Eng. Chem., 1965, 57, 49-52

14 R. A. Erb and E. Thelen, in 'Proc. First Int. Symp. on Water Desalination, 1965', U.S. Department of Interior, Washington, D.C., 1967,2 , pp. $589-602$
15 R. A. Erb, F. Phys. Chem., 1968, 72, $2412-2417$

16 R. A. Erb, T. I. Haigh and T. $M$. Downing, in 'Symp. on Enhanced Tubes for Desalination Plants', U.S. Department of Interior, Washington, D.C., 1970, pp. 177-201

17 P. Griffith and M. S. Lee, Int. F. Heat Mass Transfer, 1967, 10, 697-707

18 R. E. Tower and J. W. Westwater, Chem, Eng. Progress Symp. Ser., $1970,66,(102), 21-25$

19 D. W. Woodruff and J. W. Westwater, Int. F. Heat Mass Transfer, $1979,22,629-632$

20 D. G. Wilkins, L. A. Bromley and S. M. Read, Am. Inst. Chem. Eng. 7., 1973, 19, 119-123

21 D. G. Wilkins and L. A. Bromley, Am. Inst. Chem. Eng. F., $1973,19,839-845$

22 B. T. Nijaguna and A. H. Abdelmessih, Proc. Fifth Int. Heat Transfer Conf., 1974, 3, 264-268

23 A. H. Abdelmessih, A. W. Neumann and S, W. Yang, Letl. Heat Mass Transfer, 1975, 2, 285-292

24 R. J. Hannemann and B. B. Mikic, Int. Y. Heat Mass Transfer, $1976,19,1309-1317$

25 C. M. Detz and R. J. Vermesh, Am. Inst. Chem. Eng. J., 1976, 22, $87-93$

26 M. I. Abdul-Hadi, Can. 7. Chem. Eng., 1979, 57, $451-459$

$27 \mathrm{D}$. W. Woodruff and J. W. Westwater, 'Steam Condensation on Various Gold Surfaces', accepted for 20th National Heat Transfer Conference, Milwaukee, WII, August 1981

28 T. Smith, $\mathcal{J}$. Colloid Interface Sci., 1980, 75, 51-55

\title{
The Gold of Asante
}

\section{THE SPLENDOUR OF A NINETEENTH CENTUR Y WEST AFRICAN KINGDOM}

During the greater part of the nineteenth century the kingdom of Asante dominated the Gold Coast of West Africa. The country was rich in gold, and although great quantities were exported to Europe it was also used liberally to adorn and to glorify its rulers.

An exhibition recently mounted by the Museum of Mankind (the Ethnography Department of the British Museum), in London, clearly brings out both this spectacular use of gold and the quite extraordinary skills of the craftsmen who made the royal insignia and many other decorative objects, these exceeding by far any such manifestation elsewhere in Africa.

The casting of gold by the lost wax process was established by the end of the fifteenth century, when European trading for gold also began. Gold was in fact the basis of life and of contacts with Europe, the country being committed to a gold-dust currency which greatly facilitated trade and which led to the production of the well known 'gold weights' cast in brass in a most attractive variety of designs.

Estimates of the amount of gold produced in this region from its earliest exploitation until the end of the nineteenth century vary widely from half a million to well over a million kilograms, some part of this always being used to adorn the country's rulers. Sword hilts, neck torques, pec-

Typical of the intricacy of Asante lost wax castings in gold from the nineteenth century is this ornament, about $8 \mathrm{~cm}$ in length, depicting three highly stylized elephants with birds on their backs. It was possibly attached to the headgear of a chief or formed part of a large ring torals, rings for fingers and toes, and many other objects were cast, some of them representing animals or insects and all showing a high standard of delicacy and intricacy.

A well illustrated book by M. D. McLeod, the Keeper of the Museum of Mankind, has been published in connection with the exhibition.

L.B.H.

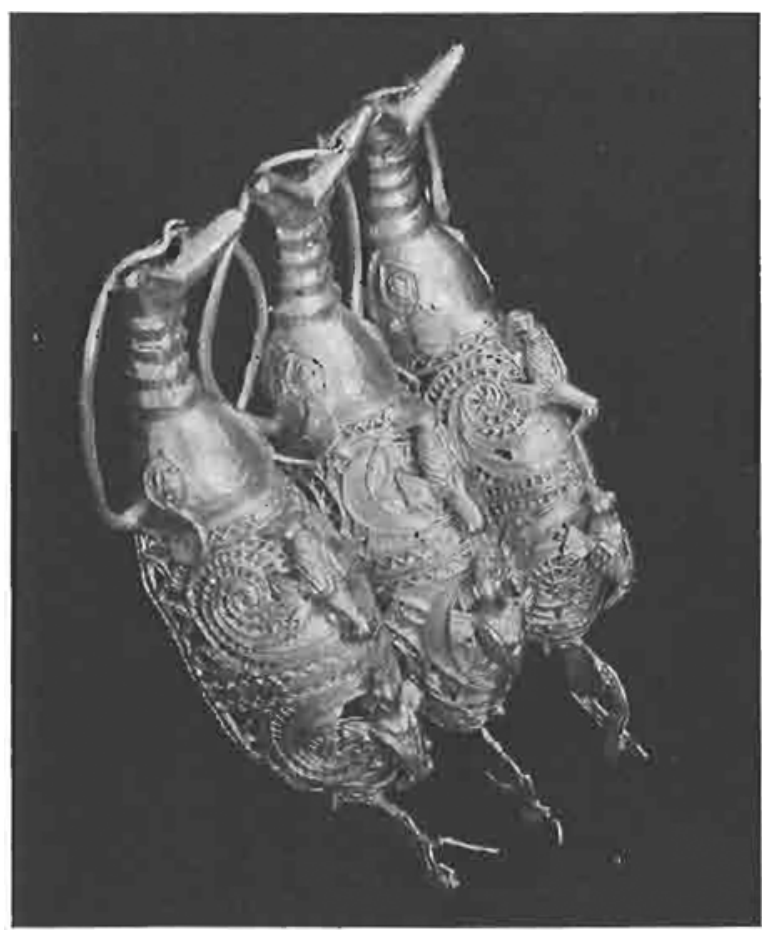

